\title{
The Objection to The Claim of Meeting The Prophet Muhammad in a State of Awakedness According to Muhammad al-Shinqīịi
}

\author{
Abdul Muthalib \\ Fakultas Ushuluddin UIN Syarif Hidayatullah Jakarta \\ daykiban@yahoo.com
}

\begin{abstract}
This paper deals with the reaction of al-Shinqitit towards this latter way of mystical vision, particularly in the case of A hmad al-Tijāni. For al-Shinqītīi, sufis' claim of having a fully consciousness physical contact with the Prophet after his death is impossible because nothing, whether religious or rational proofs, can sustain it. The extreme case of such claim is expressed by Ahmad al-Tijāni who, insists that a sufi (sūfi) can really see the Prophet with his physical eyes. ${ }^{1}$ In al-Tijanis opinion, the ability of the physical eyes to see the Prophet when awake was a common trait of those who attained the status of pole (quț). ${ }^{2}$
\end{abstract}

Keywords: Mystical vision, al-Tijānī, physical contact.

Abstrak: Tulisan ini menunjukkan reaksi al-Syinqìtī terhadap klaim visi mistis bertemu Nabi, terutama dalam kasus Aḥmad al-Tijānī. Kasus ekstrim dari klaim tersebut diungkapkan oleh Abmad al-Tijāni yang menegaskan bahwa seorang sufi benar-benar dapat melihat Nabi dengan mata fisiknya. Menurut pendapat Ahmad al-Tijānī, kemampuan mata fisik untuk melihat Nabi saat terjaga adalah ciri umum dari mereka yang mencapai status Quṭb.

Kata Kunci: Visi mistik, al-Tijānī, kontak fisik dengan Rasul. 


\section{Introduction}

Disagreements among the 'ulam $\vec{a}$ ' over certain religious issues are nothing new in Islam. Even if there are proofs from the Qur'ān and Hadìth to sustain an argument, Muslim scholars still arrive at different interpretations. Certainly, these divisions would become even more acute if there were no sources found in the Qur'ān and the Hadith that applied to the problems in question. These debates can sometimes become very harsh, even to the point of opponents accusing each other of apostasy or ignorance, such as in the case of al-Ghazālî̀s stance on Ibn Sinnās position on the eternity of the world, or Ibn Taymìya's criticism of Ibn 'Arabī's concept of monism. ${ }^{3}$ Other 'ulamä, however, have taken more moderate positions, especially in the boundaries of legal issues among the four Sunnī madhāhib, claiming that divergences and differences in religious opinions are acceptable because the Prophet himself demanded that his community tolerate different interpretations on religious issues. The Prophet, in fact, declared that differences in interpretation on religious issues in his community were the grace of God. And it is even understood by Muslim jurists that, if they correctly resolve a legal issue, they will get ten rewards; but if they are wrong, they still get one reward. Unlike the hierarchical structure in other religious traditions, there is no pontifical leader who is followed by the whole umma.

One key theological issue which was debated by Muslim scholars was the validity of the claim of meeting the Prophet Muhammad with one's physical eyes in a state of awakedness. Nor is it surprising to see that the ability to see the Prophet while awake is fiercely attacked by Ibn Taymiya who denies the possibility that one can see the dead prophets or the saints in the state of awakedness. In his book al-Jawāb al-ṣahīh li-man baddala din al-Masĭh where he criticized Christianity, he traces this claim from pre-Islam notion of Saint Paul's vision of Christ in the state of awakedness. He strongly denies Saint Paul's vision. In the same vein, he also denies the claims of some Sufis to see the Prophet in such manner. He maintains that one really sees the Prophet only in a dream. If one claims to see any prophets or any saints in awaking, what they see in fact is not true, but rather it is a sort of hallucination that is made by the Jinn. ${ }^{4}$ The same reaction appears 
in the attitude of the Mālikī Muftī of Medina, Shaykh Muhammad al-Shinqîtīi, ${ }^{5}$ who might have learned such an objection from Ibn Taymīya and Ahmad ibn Muhammad al-Qasțalānī (d.923) who had already rejected this claim in his book al-Mawāhib al-laddunnīyah bial-minah al-Muhammadìya. ${ }^{6}$

\section{Al-Shinqīṭīs book, Mushtahá al-Khärif al-Jānī fì Radd Zulaqāt al- Tijānī al-Jänì}

This objection was clearly presented by the Mālikī Muftī of Medina, Muḥammad al-Khaḍir al-Jakanī al-Shinqị̣̂i (d. 1936). AlShinqītī expressed his polemic in his book, Mushtahá al-Khārif al-Jānī fì Radd Zulaqāt al-Tijānñ al-Jānī. This book was written to challenge a work by the Moroccan Tijānīya shaykh, 'Alī Kharāzim ibn 'Arabī alBarāda (1799-1856), entitled, Jawāhir al-Ma '̄ñ̄ wa Bulūgh al-Amānī fì Fayd Sayyidì Abì al-'Abbās al-Tijānī. 'Alī al-Barāda states therein that he met Aḥmad al-Tijānī on 27 Sha'bān 1216 A.H., or January $2^{\text {nd }}, 1802$ and claims that the book was written under direct dictation from the latter. ${ }^{7}$

Let us turn to al-Shinqītī's book. Its main feature is a sharp critical argument against șüfì ideas and practices. But his criticism is not addressed to all șüfì traditions and teachings because, as we learn from it, it is clear that he still respects the sufi and shares in many views with them. His sharpest critiques are focused on șüfì visionary experiences of the Prophet Muhammad, which he details in chapter three of the work. First, he wages a polemic against those who claimed to have seen the Prophet while awake. Next, he rejects the possibility of such tremendous miracles. Following this, he denies the religious value of the stories of meeting the Prophet Muhammad in a state of awakedness after his (the Prophet's) death and receiving religious guidance from him. Finally, he rejects unhistorical definitions of the Companions.

It is very strange, says al-Shinqītīi, that later generations have claimed to have had these experiences. In this regard, he mentions several names, such as al-Suyūțī, Abī Hamza, 'Afîf al-Yāfíī, and Șayf al-Dīn al-Manșūr, not to mention al-Shinqīṭ̣̂’s favourite target, Aḥmad al-Tijānī. 


\section{Aḥmad al-Tijānī and Muhammad 'Abd al-Karīm al-Sammān}

There is no doubt that Aḥmad al-Tijānī had been influenced by one of the most important șūfī figures of the $18^{\text {th }}$ century, Shaykh Muhạmmad 'Abd al-Karīm al-Sammān (1717-8-1775) whose influence extended to various parts of the Muslim world, such as the Sudan, Eritrea, Afghanistan and Southeast Asia. However, his strongest influence was to be in Indonesia and the Sudan. ${ }^{8}$

Even though al-Shinqị̣̂i does not include Muhammad 'Abd alKarīm al-Sammān's name in the list of those who espouse such idea, it appears that he was no aware that al-Sammān also adopts it. As we learn from al-Futūhāt al-Ilāhīyah of al-Sammān, it is clear that al-Sammān can even be considered among the pioneers on the cult of the Prophet Muhammad. For și fi while awake is the most tremendous experience that a human being can hope for. Al-Sammān claims that he himself and Shaykh Ahmad al-Qushāshī experienced this event. ${ }^{9}$ For al-Sammān, since the Prophet is the mediator between God and his servants, the meeting with the physical body of the Prophet while awake is an event that every Muslim must strive to experience. According to him, a believer can converse with the Prophet and ask him anything, and the Prophet will answer, all in a state of awakedness. ${ }^{10} \mathrm{Al}$-Sammān does not doubt that the deserving siuf $\bar{i}$ will gaze at the very face of the Prophet when fully awake and in real time. The founder of the Sanūsìya tarīqah, al-Sanusi relates that al-Sammān categorizes the Sufis who obtain the spiritual vision in two groups; the first one is those who encounter such vision in the state of awakedness in which both his inner eyes and his physical senses involve; they are graced by God to see something supernatural which occur starting through his khayall (imagination) to his physical senses. The latter is only to see it in a dream in which the physical eyes do not involve at all. ${ }^{11}$

Al-Sammān may well have inspired al-Tijānī to speak in terms of a direct contact with the Prophet. As 'Alī al-Barāda tells us, it was upon the suggestion of Ahmad ibn 'Abdilllāh al-Hindī'12 that Ahmad al-Tijānī met al-Sammān when he visited Medina after completing his hajj and decided to study with him. Even though he only stayed with al-Sammān for three days, he acquired a great deal of esoteric 
knowledge from him. ${ }^{13}$ Al-Barāda does not specify what kind of esoteric knowledge al-Tijānī learned, except that he later admitted in a letter that al-Sammān had initiated him into the $a b z a b$ of the Shādhilīya, the wazîfah of Muhammad al-Zarrūq, and the daläil al-khayrät, which he kept practicing even after founding his own Tijānīya țarīqah. ${ }^{14}$ In addition, it is obvious that Ahmad al-Tijānī knew the teachings of al-Sammān on the visualization of the light of Muhammad, either through the Futūhät al-Ilāhìyah, or at least via his earlier direct contact with him. In al-Tijānī’s mystical teaching, al-Sammān's ideas are expressed and the influence of his Futūhāt alIlāhiyah is clearly discernable. Another remarkable fact is that Ahmad al-Tijānī also shared with al-Sammān's Southeast Asian students in adopting the concept of the seven levels of existence (martabat tujuh). ${ }^{15}$ The pioneer of this concept was al-Burhānpūrī in his Tuhfat al-Mursalah and, as we learn from 'Abd al-Șamad al-Palimbānī, it was al-Sammān, who asked al-Palimbānī to read the Tuhfat al-Mursalah with 'Abd al-Raḥmān ibn 'Abd al-'Azīz.

Moreover Aḥmad al-Tijānī claimed a status superior to that of previous sufi by virtue of his having been directly initiated by the Prophet himself and his having been ordered to build a new tariqa. In this regard, it was the Prophet himself who was his direct master. ${ }^{16}$ Thus, there is no name prior to his in the silsilah of his tariqah, other than that of the Prophet. The Prophet told him to abandon all the tariqas that he had belonged to, and only concentrate on this new one. This new tariqa would be easy to practice but more effective in gaining salvation. The Prophet supposedly said, "Concentrate on this effective tariqa without being busy with retreat and seclusion from people, and ignore all saints." ${ }^{\prime 17}$ The other tariqas that al-Tijānī had already adopted from șūfī shaykhs became invalid for him, except as means of acquiring benediction (lil-tabarruk). ${ }^{18}$ In the same vein, the most striking requirement of initiation into the Tijānīya tariqa is that one must withdraw all membership from and practice of other tariqas. ${ }^{19}$ This new, innovative demand became one of the most controversial issues surrounding Aḥmad al-Tijānī’s teaching. Most of the meetings of al-Tijānī with the Prophet occurred in a state of awakedness and with his real, physical eyes. 


\section{Al-Shinqīịị’s Arguments Against such Visions}

The claim of having such an extraordinary vision is debated by al-Shinqīṭi. As we will explain in more detail later, al-Shinqīṭi affirmed that there was no religious proof for believing in such visions. He relates that those who support or agree with such claims have misunderstood the Hadìth narrated by both al-Bukhārī and Muslim about the Prophet's statement that whoever saw him in a dream, would see him while awake as well. In fact, this Hadith was interpreted in many ways, seven of which are of particular interest. The first interpretation is from Ibn Tīn who explained it as meaning that everybody who believed in the Prophet, but had not seen him at some point, would see him while awake before dying. The second interpretation, according to Ibn Batțāl, is that after one has dreamt of the Prophet, one can only interpret that dream after waking up or when awake. The third interpretation is that this Hadith refers to a likeness; that is, if one dreams of seeing the Prophet, then this will lead him to be in a state similar to seeing the Prophet while awake.

The fourth interpretation is that one can only see the image of the Prophet in a mirror. According to Ibn Hamza, this is what happened to Ibn 'Abbās who dreamt of the Prophet and after awakening from sleep, then remembered this Hadith. He then went to see the wives of the Prophet and perhaps it was Maymūna who showed him a mirror belonging to the Prophet. What Ibn 'Abbās saw in that mirror was not a reflection or image of himself, but rather an image of the Prophet. The fifth interpretation is that everybody, regardless of whether he or she dreams of him or not, will see him in the hereafter. According to Qàḍi 'Iyāḍ, it is possible that the dreamer really sees his real attributes. However, it is also possible that the great sinners will not see him in the hereafter, even once. Al-Shinqītī tends to favor this interpretation. The most important condition is that a believer must die in Islam (husn al-khätimah).

The sixth interpretation only insists that the meaning of the Hadith is not that one will see the real figure or image of the Prophet, but rather will see him in an allegorical sense related to the Islamic religion and its laws; that is, the dreamer will see the Prophet's religious qualities. The seventh interpretation-to which al-Shinqīṭi 
objects most strenuously-is that one will actually see the Prophet in a state of awakedness after his death. According to Ibn Hamza, there were a great number of pious believers who claimed to have had such experiences; first, they saw him in a dream, but then later they saw him while fully awake and used the opportunity to ask questions about a variety of subjects. ${ }^{20}$

According to al-Shinqītị, Muslim scholars are divided over the possibility of meeting the Prophet Muhammad in a state of awakedness. He relates that Jalāl al-Dīn al-Suyūṭī insisted on the possibility of such an event, and even claimed that his mastery of the science of the Hadith was due to the direct guidance of the Prophet who appeared to him while he was completely awake. ${ }^{21}$ Al-Shinqītī denies this possibility and expresses deep regret that al-Suyūṭî, despite his extensive knowledge and memorization of the Hadith, could not corroborate this event with any kind of Hadiths (whether sahīh or $d a$ 'if, marfü 'or mursal), or from the experiences of the Companions and the generation after the Companions. ${ }^{22}$ According to Shinqītī, the claim of having met the deceased Prophet, in his real essence and while fully awake, is rejected by most Muslim scholars because it has no foundation in the Qur'ān, the Hadìth or the accounts of the Companions and the Prophet's family.

According to al-Shinqītī the early Islamic umma, namely, the Companions of the Prophet, were the best generation of the Islamic community. After the prophets and the elite angels, the first generation of Muslims - namely, the Companions of the Prophetwere spiritually superior to all other creatures. ${ }^{23}$ In this regard, he cites several Hadiths which confirm their important status. "The Prophet said that the best generation was his generation which was then followed by the second and third generations." ${ }^{24}$ The Prophet assured his followers that those who saw him and those who saw those who saw him would be saved from hell. ${ }^{25} \mathrm{He}$ also explained that his Companions, the Täbi in (the second generation after the Companions) and the Tăbi' al-Tăbi'in (the third generation) were religiously the most fortunate people. The Prophet equated the function and role of the Companions in the Islamic community to that of salt; no food would be as good without it. ${ }^{26}$ Thus, al-Shinqīṭi 
believes that later generations become less spiritually significant, an idea that was rejected by the earlier sufi al-Hakìm al-Tirmīdhī. ${ }^{27} \mathrm{Al}-$ Shinqî̀i ridiculed the notion that somebody living twelve centuries after the Hijrah could claim that he was superior to any of the prophets, perhaps alluding here to the claim of the Tijāniya that Ahmad al-Tijānī was superior to the Prophet Khiḍr.

Al-Shinqītī disagreed with the view that the miraculous events of later generations could surpass those of the ones closest to the family of the Prophet and his Companions. And especially with regard to fully consciousness physical contact with the Prophet after his death, he says that if this could really take place, it would also have occurred to the family of the Prophet and his closest Companions, and would have been recorded, at least, in the lives of the two important people who were historically and psychologically closest to the Prophet; namely, his daughter Fāțima and his Companion 'Umar ibn alKhațāb. Despite the fact that the Prophet's daughter Fațima was despondent after the Prophet's death and had chosen to live near his tomb, she never experienced meeting the Prophet in a state of awakedness. ${ }^{28}$ Again, the Companions of the Prophet were at times in serious need of the presence of the Prophet, especially when faced with serious disputes about religious and worldly affairs, but the Prophet never appeared to assist them. That is why when 'Umar ibn al-Khațāa faced difficulties in leading the umma, he used to wish that he could ask the Prophet to help him solve his problems. ${ }^{29} \mathrm{Al}-$ Shinqītị also argues that the early sufi masters never claimed that they had met or had been initiated by the Prophet directly. That is why the chain of tariqa masters is still important to all sufi orders. It is clear that this critique was directed at al-Tijānī's founding of a new tariqa, supposedly under the direct guidance of the Prophet.

In expressing his doubt about some sufi's claims to having met the Prophet while fully awake, al-Shinqītî cites al-Qurțubỉs strong objections to the idea. Basing himself on what seems to be a rationalist approach, al-Qurțubi disagrees with the opinion that what one sees in a dream is the actual reality of the Prophet and especially with the idea that one could see him in a state of awakedness. Al-Qurtubī ridiculed such claims by saying, "If one can see the Prophet after his 
death, he must have seen him in a condition when he had passed away; thus, this vision is rationally nonsense.” And al-Qurțubī insists on the impossibility of both reawakening of the Prophet from his tomb to communicate with his living followers. If this were possible, there would be no use in visiting the tomb of the Prophet because he would not be there.

In denying the possibility of this experience, however, al-Shinqịtī seems to reserve most of his disapproval for the Tijānīya. He does not attack other pious believers' claims about such experiences directly, but rather agrees with Badr al-Din al-Ahdal who argued that these pious believers had honestly exposed their spiritual experiences of visions of the Prophet in a state of awakedness. Therefore, it would be hard to deny them. Thus, in order to correctly understand them and avoid judging them unfairly, we should not take their statements literally. This kind of event may have constituted a spiritual experience, beyond the boundaries of human physical senses; it is inexplicable because it is a very personal experience. However, al-Ahdal also argues that most of the accounts of such visionary experiences were in fact wrong or just a product of the imagination.

Furthermore, some of them experienced this phenomenon in a dream or spiritually, but thought that they had done so while awake and with their physical vision. Some in fact only had hallucinations. For example, they would see a sort of light and think that it was the Prophet. And, it is possible too that it was satan who deceived them by whispering to them that they had seen the Prophet physically and while awake. Satan frequently used to try to deceive Shaykh 'Abd al-Qādir al-Jīlānī, appearing to him in a cloud, telling him that he was God and advising him to ignore religious laws. But, he failed to deceive him because al-Jîlānī was aware that God would not do such things. ${ }^{30}$ According to al-Shinqītī, dreaming of a vision of the Prophet is secured from the deception of satan because the Hadith assures us that if somebody dreams of seeing the Prophet, he really sees him, even though many 'ulamä'still considered such a vision part of the realm of the imaginal. But, seeing the Prophet while awake is not secured at all from satanic deceptions, because there is no single Hadith that confirms this. Certainly, the Prophet assured his followers 
that satan cannot imitate his image, but this is only in the case of a vision in a dream. A grave risk is posed when this vision comes during a state of awakedness. This is not because satan resembles the Prophet, but because someone may mistake satan for the Prophet. Al-Shinqīṭi maintains that this was maybe the case with Ahmad al-Tijānī. Satan may have appeared to al-Tijānī, who might have taken him for the Prophet. ${ }^{31}$ Yet, despite how critical al-Shinqītī was of al-Tijānī, he did not completely deny other sufi's stories when they claimed having experienced such visions; he was still willing to trust their stories on the condition that these stories were not be understood literally.

In this regard, he relates how al-Ahdal understood correctly the story of Abū al-'Abbās al-Mursī's vision of the Prophet. Shaykh Abū al-'Abbās al-Mursī, the teacher of Ibn 'Atạà Allāh al-Iskandarī said, "If the Prophet were veiled from his vision in a single instance, he would consider himself an infidel." According to al-Shinqīṭi, al-Ahdal argued that this statement does not really mean that al-Mursī kept seeing the spirit of the Prophet, but rather that he kept imagining the presence of the Prophet at every step of his actions and utterances. ${ }^{32}$ Al-Shinqītī rejects al-Tijānī's literal interpretation of al-Mursī's statement. According to al-Tijānī’s student 'Alī al-Barāda, al-Mursī really saw the Prophet with his physical eyes. In al-Tijānī's opinion, the ability of the physical eyes to see the Prophet when awake was a common trait of those who attained the status of pole $(q u t b))^{33}$

Like other Sunnī scholars, al-Shinqīṭi does not deny the existence of saints among the faithful because he believes that this concept is traceable to the Qur'ān, the Hadīths and the opinions of Muslim scholars. ${ }^{34}$ Unlike Ibn Taymìyah, ${ }^{35}$ al-Shinqītī does not deny the existence of a hierarchy of saints, such as pole (quț), 'abdāl, afräd, etc. However, it seems that he believes that the status of sainthood is not a mater of human affairs, but subject to God. Thus, he was skeptical when people declared somebody a saint. It is not impossible, he says, that somebody who was not a saint but was popular, might be considered a saint by many people. ${ }^{36}$ For example, al-Shinqīṭi argues that the designation "pole" can only be bestowed on one person in every generation; nevertheless, it would seem that there were many poles in every generation. Thus, al-Shinqītī concludes that these 
claims could be completely wrong and untruthful. ${ }^{37}$

Also, with regard to the saints' miracles, like other Sunnī scholars, al-Shinqî̀ī does not deny the existence of miracles at the hands of saints or that the prophets could make miracles through the efforts of saints. It is obvious that al-Shinqịtī agrees that it is obligatory to believe in the miracles of the prophets but is in complete disagreement with the idea that it is obligatory to believe in the miracles of saints, such as Abū Jamrahs statement that the meeting of a saint with the Prophet in a state of awakedness must be recognized by every Muslim. Al-Shinqīṭi insists that to believe in the miracles of saints is only an optional matter; it is absolutely not an obligation. Thus, sufi's stories about their supernatural experiences such as miracles, enlightenment, unveiling and their ecstatic statements cannot be automatically admitted by a believer. If their claims cannot be traced to the Qur'an, the Hadiths or the accounts of the Companions, it is permissible to deny them.

Al-Shinqịṭī was aware that Abū Isḥāq al-Isfarāyinī rejected the possibility of the similarity of saints' miracles to those of the prophets, but he did not agree with the latter; rather, he insisted that two varieties can be similar in quality. However, when al-Shinqīṭi raised a question as to whether it was possible that the saints might have the experience of meeting with the spirit of the Prophets, such as what happened to the Prophet Muhammad when he had a vision of Moses praying at his tomb or when he met other prophets during his ascension to heaven, al-Shinqî̀tī avoided answering this question directly, but appears to have disapproved of it. It seems that his disapproval was not like that of al-Isfarāyinini, but was based on the irrationality of the stories told by these claimants. Thus, the claim by a great number of believers that they saw the Prophet Muhammad and other prophets was rejected by al-Shinqịti because many of them pretended to have seen the Prophet in different places at the same moment.

Al-Shinqị̂i does not refute the connection between spirit and body; but the spirit must only be connected with a single body at any given moment, not with various bodies. ${ }^{38}$ Thus, like al-Qurțubī, al-Shinqî̀t in insists on the impossibility of multiple appearances of the Prophet in various places at the same time. According to al-Shinqìtīi, 
the Hadith of the mírāj clearly shows that the Prophet Muhammad did not see Moses and the other prophets in different places at the same moment. The Prophet saw Moses praying at his own tomb and then saw him again in heaven, but never at the same moment. The first meeting in fact happened during his journey to Jerusalem; while the second occurred during his actual ascension to heaven. Al-Shinqītị also rejects the opinion that the prophets' appearances are similar to the rays of the sun which can be seen in different places.

According to al-Shinqītīi, this opinion is obviously wrong and irrational because even though the light of the sun can be seen anywhere; it nevertheless always shines in one certain direction, not everywhere. In the same vein, it is obviously impossible that one should see A at his own house and B at his own house at the same moment. However, al-Shinqītī does not completely reject the possibility of such visions; rather, he only states that this kind of vision is likely to happen within the realm of the imaginal. To substantiate his position, he refers to Abū Hāmid al-Ghazālì who says, "What the Prophet means by 'see me in the state of awakedness' does not mean to 'see my real physical body,' but rather an imaginably vision." This is like how one sees God in a dream; it does not mean that one really sees God, because His true essence is devoid of forms and images. ${ }^{39}$

Another reason for the impossibility of seeing the Prophet in a state of awakedness is the factor of the unequal nature of the spirit of the Prophet with the living believers. According to al-Shinqītī, the meeting between two individuals must be conditioned by their similar states in nature. Thus, it is impossible that the living and the dead should see each other and have real physical contact. The claim to having seen the Prophet when awake and with real physical eyes is impossible because of, to repeat, the different nature of the spirit of the Prophet after his death from that of his living followers. The existence of the spirit of the Prophet is in the eternal world, whereas the existence of the spirit of his living followers is still in this non-eternal world. Therefore, the eyes of those who belong to the non-eternal world (the lower realm) are not capable of seeing the ones who belong to the higher realm. For instance, no one can see the real transcendental form of the angels, except the Prophet 
Muhammad who saw one in such a manner only twice. Furthermore, this happened because the Prophet himself was transformed into the state of the angelic realm. Because they both shared the same nature of existence, they could meet each other. By the same token, the Companions saw the Angel Gabriel not in his real nature, but rather after the transformation of Gabriel's angelic transcendental form into human form, which brought him down to the lower realm. ${ }^{40}$

\section{Al-Shinqīṭī Critique to al-Tijānī's Unhistorical Definition of What it Meant to be One of the Sabābab}

Yet another controversial claim by al-Tijānī that was refuted by al-Shinqīṭi was his unhistorical definition of what it meant to be one of the Sahäbah. Nevertheless, as I have pointed out before, such a definition is not in fact adopted by all those who accept the possibility of meeting the Prophet in a state of awakedness, such as al-Suyūtị. AlShinqīṭi also rejects the unhistorical definition of Șahäbah which was adopted by some later sufi. According to this new definition, anybody who, while awake, meets the Prophet after the Prophet's death can be classified as one of the Prophet's Companions. Al-Shinqītī’s definition only includes those believers who met the Prophet during the earthly lifetime of the Prophet. Thus, anybody who meets the Prophet after the Prophet's death in a dream or in some other imagined way (for example while awake) cannot be included among the Companions of the Prophet in al-Shinqîțī’s view. ${ }^{41}$ Al-Shinqịṭī ridiculed al-Tijānī’s claim to be one of the Companions. "It is very odd that one who lived in the twelfth-century Hijrah should include himself among the Companions." ${ }^{\not 2}$ It is clear that in claiming this status, al-Tijānī was inspired by al-Sammān. For, as we learn from al-Futūhāat al-Ilāhìya, al-Sammān insists that those sufi who met and communicated with the Prophet in a state of awakedness attained a status like that of the Companions. ${ }^{43}$ Al-Sammān also experienced such a vision, and that is why his Manāqib includes him as one of the Companions. ${ }^{44}$ It is clear that his position is not different from that of Ibn 'Arabī who maintained that a man who meets the Prophet in such a manner (awake, not asleep) can be among the Companions. ${ }^{45}$

It is rightly to assume that al-Shinqịțīs disapproval to this position 
might have been inspired by al-Suyūṭi who had already insisted that only the historical definition of the Șahābah is valid. Al-Suyūtị insists that the meeting between a believer and the essence of the Prophet after his death does not happen in 'älam al-mulk (worldly life), but rather in the 'allam al-malaküt. And, because such a meeting happens only in the angelic realm, nobody can claim that he should be considered one of the Companions of the Prophet. Al-Suyūtī sustains his position by arguing that all the Prophet's followers (all Muslims) will see the Prophet and he will see them too on the Day of Judgment; in this case, however, the designation "Companion" cannot be attributed to all of them because this vision is in the angelic realm. ${ }^{46}$

\section{Conclusion}

Al-Shinqītị’s rejection to the possibility of sufi' visions of the Prophet in the state of awakedness is a reflection of the position of the jurists and the theologians against this new trend of sufis' excessive claim. They saw this tendency to be strange and perhaps can be dangerous for the orthodoxy of the pristine Islam. Al-Shinqitị̂s position is also a response of the orthodox 'ulama to the suspicious trends of the Sufis who espouse the validity of their mystical intuition and revelation through their encounter with the post-mortem existence of the Prophet. Thus, the response of al-Shinqītī is directed to challenge the authority of the charismatic sufi leaders which may lead to undermine the religious authority of the Muslim jurists and theologians.

\section{Endnotes:}

1 See Muhammad 'Abd al-Karīm Sammān, al-Nafahāt al-Ilāhīyah fì Kayfìyat Sulūk al-Ṭariqah al-Muhammadiyya (Cairo: Maṭba'at al-Ādāb, 1908-9), 59. Further detail on the reality of Muhammad, see Michel Chodkiewicz, Le Sceau des saints: prophétie et sainteté dans la doctrine d'Ibn Arabî (Paris: Gallimard, 1986), 79-94.

2 'Alī Barāda Harāzim ibn al-'Arabī. Jawāhir al-Ma'ānì wa-al-Bulūgh al-Amānī: fì Fayd Sayyidì Abì al-Abbās al-Tijānì (Beirut: Dār al-Kutub al-'Ilmīyah, 1997) vol. 1, 275.

3 On Ibn Taymìya's critique of Ibn 'Arabī, see Alexander D. Knysh, Ibn 'Arabi in the Later Islamic Tradition: The Making of a Polemical Image in Medieval Islam (Albany: State University of New York Press, 1999), 87-106. See also 
Muhạmmad Rashād Sālim, Muqārana bayna al-Ghazālì wa-Ibn Taymīya (Kuwait: Dār al-Qalam, 1975), 101-112.

4 Ibn Taymīyah, al-Jawāb al-Ṣahīh li-Man Baddala Dīn al-Masīh (Miṣr: Maṭba'at al-Nìl, 1905), Vol 2, 324, 326, 329.

5 See Muhammad al-Shinqīṭī, Mushtahá al-Khārif al-Jānī fì Radd Zalaqāt alTijānī al-Jānì (Amman, Jordan: Dār al-Bashīr, 1985), 30-141.

${ }^{6}$ Aḥmad ibn Muhammad ibn Muhammad al-Qasṭallānī, al-Mawāhib alladunìyah bi-al-minaḥ al-Muhammadīyah, taḥīi Șāliḥ Aḥmad al-Shāmī (Bayrūt: al-Maktab al-Islāmī, 1991), 292-301.

7 'Alī Barāda, Jawāhir al-Ma'ānī wa-al-Bulügh al-Amānì, vol.2, 452.

8 Two of al-Sammān's direct students, 'Abd al-Ṣamad al-Palimbānī and Muhammad Arshad al-Banjārī as well as his indirect student Muhammad Nafīs al-Banjārī, became leading sufi figures in Southeast Asia in the $18^{\text {th }}$ century. 'Abd al-Ṣamad al-Palimbānī's works Siyār al-Sālikīn and Hidāyat al-Sälikìn as well as Muhammad Nafīs' work al-Durr al-Nafìs, all of which were written in Jawi (Indonesian in Arabic script), frequently quote al-Sammān and remain popular sufi literature amongst Southeast Asian Muslims up to the present day. The Sammānīya-Khalwatīya tariqa developed in several parts of the Indonesian archipelago such as Makasar, Aceh, South Kalimantan, Palembang and Minangkabau. The popularity of al-Sammān was intensified in the region through his hagiography Manāqib Muhammad al-Sammān, which seems to have been written immediately after his death by his two students Șiddīq ibn 'Umar Khān and 'Abd al-Raḥmān al-Maghribī, and then translated into Jawi in the $18^{\text {th }}$ century. Al-Sammān's popularity was very strong in Indonesia and in fact was even greater than that of Ahmad al-Qushāshī, who also had a great influence on the region in the $17^{\text {th }}$ century via his two Indonesian students, 'Abd al-Ra'ūf and Yūsuf al-Makassarī.

9 Muhammad 'Abd al-Karīm Sammān, al-Nafahāt al-Ilāhīyah fì Kayfiyyat Sulūk al-Ṭaìqah al-Muhammadìyah (Cairo: Maṭba'a al-Ādāb, 1908-9), 65.

${ }^{10} \mathrm{Al}$-Sammān, al-Futūhāt al-Ilāhīyah fì al-Tawajjuhhāt al-Rūhìyah (MS. Cairo: (AZ) 602),3.

${ }^{11}$ Muhammad al-Sanūsī, Kitāb al-Masāì al-Aṣr, al-Musammā bi-Bughya alMaqūṣid fì Khulāṣat al-Marāṣid: wa-bi-Hāmishihī Kitāb al-Salsabīl al-Mu'ìn fì al-Ṭääiq al-Arba'in (Cairo: Maṭa'at al-Ma'̄āhid, 1934), in Kitāb al-Masāil al'Aṣr, al-Musammá bi-Bughya al-Maqūṣid fì Khulāsat al-Marāṣid, 187-188.

12 'Alī Barāda, Jawāhir al-Ma'ānì wa-al-Bulūgh al-Amānī, vol. 1, 37-38

13 'Alī Barāda, Jawāhir al-Ma'ānì wa-al-Bulügh al-Amānī, vol. 1, 38.

14 'Alī Barāda, Jawāhir al-Ma'ànī wa-al-Bulügh al-Amānī, vol. 2, 360.

15 'Alī Barāda, Jawāhir al-Ma'ānī wa-al-Bulūgh al-Amānī, vol. 2, 253.

16 'Alī Barāda, Jawāhir al-Ma'ānì wa-al-Bulügh al-Amānī, vol. 1, 40.

17 'Alī Barāda, Jawāhir al-Ma'ànī wa-al-Bulügh al-Amānì, vol. 1, 40-41.

${ }^{18}$ Especially his connection to the Khalwatiya tariqa, that he had taken from Maḥmūd al-Kurdī in the chain which goes back to Muștafā ibn Kamāl al-Dīn al-Bakrī, see 'Alī Barāda, Jawāhir al-Ma'ānì wa-al-Bulūgh al-Amānī, vol. 1, 39. 
19 'Alī Barāda, Jawāhir al-Ma'ānī wa-al-Bulügh al-Amānī, vol. 1, 91.

${ }^{20}$ Al-Shinqīṭī, Mushtahá al-Khārif al-Jānī fì Radd Zalaqāt al-Tijānī al-Jānī, 92-93.

${ }^{21}$ Al-Shinqīịì, Mushtahá al-Khārif al-Jānì fì Radd Zalaqāt al-Tijānī al-Jānī, 118.

${ }^{22}$ Al-Shinqītīi, Mushtahá al-Khārif al-Jānī fì Radd Zalaqāt al-Tijānī al-Jānī, 91.

${ }^{23}$ Al-Shinqīṭī, Mushtahá al-Khārif al-Jānī fì Radd Zalaqāt al-Tijānī al-Jānī, 158.

${ }^{24}$ Al-Shinqīị̄i, Mushtahá al-Khārif al-Jānì fì Radd Zalaqāt al-Tijānī al-Jānī, 523.

${ }^{25}$ Al-Shinqīịī, Mushtahá al-Khārif al-Jānì fì Radd Zalaqāt al-Tijānī al-Jānī, 524.

${ }^{26}$ Al-Shinqīịī, Mushtahá al-Khārif al-Jānì fì Radd Zalaqāt al-Tijānī al-Jānī, 525

${ }^{27}$ Muhammad ibn 'Alī al-Hakīm al-Tirmīdhī, Kitāb Khatm al-Awliyä' (Beirut: alMaṭba'at al-Kāthūlīkīyah, 1965), 430. See also Abdul Muthalib "The Mystical Thought of Muhammad Nafīs al-Banjārī: An Indonesian Sūfī of the Eighteenth Century.” M.A. Thesis, Mcgill University, Montreal, 1995, 45.

${ }^{28}$ Al-Shinqīṭī, Mushtahá al-Khārif al-jānī fì Radd Zalaqāt al-Tijānī al-Jānī, 91.

${ }^{29}$ Al-Shinqīịi, Mushtahá al-Khārif al-Jānì fì Radd Zalaqāt al-Tijānī al-Jānī, 100.

${ }^{30}$ Al-Shinqīịī, Mushtahá al-Khārif al-Jānì fì Radd Zalaqāt al-Tijānī al-Jān̄̄, 108.

${ }^{31}$ Al-Shinqītị, Mushtahá al-Khärif al-Jānī fì Radd Zalaqāt al-Tijānī al-Jānī, 109.

${ }^{32}$ Al-Shinqīṭī, Mushtahá al-Khārif al-Jānī fì Radd Zalaqāt al-Tijānī al-Jānī, 98.

33 'Alī Barāda, Jawāhir al-Ma'ānī wa-al-Bulūgh al-Amānī, vol. 1, 275.

${ }^{34}$ Al-Shinqīịī, Mushtahá al-Khārif al-Jānī fì Radd Zalaqāt al-Tijānī al-Jānī, 465.

${ }^{35}$ According to Ibn Taymìyah, there is no such concept of the forty 'abdāl, etc. in Islam. This idea, he says, is similar to Shī'ism. See Ibn Taymīya, Majmū' Fatāwā al-Shaykh al-Islām Aḥmad Ibn Taymìyah (Rabaṭ: Maktabat al-Maārif, 1981), vol. 7, 57.

${ }^{36}$ Al-Shinqīịī, Mushtahá al-Khārif al-Jānī fì Radd Zalaqāt al-Tijānī al-Jānī, 505.

${ }^{37}$ Al-Shinqīịī, Mushtahá al-Khārif al-Jānì fì Radd Zalaqāt al-Tijānī al-Jānī, 508.

${ }^{38}$ Al-Shinqīịī, Mushtahá al-Khārif al-Jānì fì Radd Zalaqāt al-Tijānī al-Jān̄̄, 112.

${ }^{39}$ Al-Shinqītị, Mushtahá al-Khärif al-Jānī fì Radd Zalaqāt al-Tijānī al-Jānī, 105.

${ }^{40}$ Al-Shinqīịī, Mushtahá al-Khārif al-Jānì fì Radd Zalaqāt al-Tijānī al-Jān̄̄, 110.

${ }^{41}$ Al-Shinqīịī, Mushtahá al-Khārif al-Jānì fì Radd Zalaqāt al-Tijānī al-Jānī, 141.

${ }^{42}$ Al-Shinqīịī, Mushtahá al-Khārif al-Jānī fì Radd Zalaqāt al-Tijānī al-Jānī, 399.

${ }^{43}$ Al-Sammān, al-Futūhāt al-Ilāhìyah, 7.

${ }^{44}$ Ahmad Purwadaksi Ratib Samman dan Hikayat Syekh Muhammad Samman: Suntingan Naskah dan Kajian Isi Teks (Jakarta: Djambatan Yayasan Naskah Nusantara, 2004), 219.

${ }^{45}$ Fritz Meier, Nachgelassene Schriften: Vol. 1: BemerkungenzurMohammedverehrung (Leiden: Brill, 2005), ed. Gudrun Schubert., 385.

${ }^{46}$ Al-Shinqīịī, Mushtahá al-Khārif al-Jānī fì Radd Zalaqāt al-Tijānī al-Jānī, 265. See also Jalāl al-Dīn Suyūțī, al-Hāwì lil-Fatāwì fì al-Fiqh wa-'Ulūm al-Tafsìr waal-Hadìth wa-al-Ușūl wa-al-Nahw wa-al-I'rāb wa-Säir al-Funūn (Cairo: Idārat al-Ṭibā'ah al-Munīrīyah, 1933.) Vol 2, 80. 